\title{
The impact of the cohesion policy on the quality of life in big cities in Mazovia
}

\section{Marta Mackiewicz, Ewelina Szczech-Pietkiewicz}

\begin{abstract}
Contemporary urban policies pay great attention to improving the quality of life of the inhabitants. Such an increasing interest in the quality of life is caused by its crucial importance for the location decisions of households and businesses. In recent years, urban development has been largely financed by EU cohesion policy funds. The paper intends to identify the areas in which the quality of life of the inhabitants of large cities in Mazovia has improved thanks to the implementation of cohesion policy. The study took into account large cities in Mazovia with over 100,000 inhabitants, i.e. Warsaw, Radom and Plock.

The survey is based on data collected for the research project: ,The impact of the cohesion policy on urban development in 2007-2013', provided by the Ministry of Development. This includes in-depth interviews with representatives of units responsible for development strategy in the cities covered by the survey and a questionnaire survey among beneficiaries of projects co-funded by EU funds. An analysis of databases of projects implemented in large cities in Mazovia, financed with the participation of EU funds, as well as a research of literature on the quality of life in cities in Mazovia were also conducted. The results indicate that the inhabitants see the most improvement in the quality of life in connection with better transport in the cities. The quality of life has increased thanks to faster and more comfortable commuting to work, which leaves more time for other activities and spending free time.
\end{abstract}

Key words: cities, cohesion policy, quality of life, Mazovia

\section{Introduction}

The European Union's regional policy is based on the premise that the structural funds can be a positive factor in local economic development. Thanks to the cohesion policy, cities have been able to obtain resources to deal with many problems associated with the growth of urban agglomerations. For example, as cities develop, environmental problems reducing the quality of life, such as air pollution and disappearance of green spaces, are becoming more common [Robinson et al. 2012; Thompson et al. 2012; Mitchell 2013; Cloutier 2014]. Taking into account the importance of EU funds in urban development, their impact on the quality of life should be examined. The goal of the paper is to identify the areas in which the quality of life of the inhabitants of large cities in Mazovia have improved thanks to the implementation of cohesion policy. The article attempts to answer the research questions: Have the investments financed by structural funds had a significant impact on the quality of life of the inhabitants of large Mazovian cities? In which areas have the structural funds had the greatest impact on the economy of the cities? 
The analyses took into account large cities located in Mazovia with more than 100,000 inhabitants, i.e. Warsaw, Radom and Płock. Warsaw is classified as a metropolis and Płock and Radom as subregional centres.

Economic theory indicates that the implementation of any intervention leads to external benefits but also costs [Stiglitz 2004; Johnson 2012]. It is related to the fact that public intervention, over projects implemented without any direct beneficiaries, affects a wider range of recipients, regardless of their will. It is particularly important to identify such benefits, which are not expressed by indicators but their occurrence constitutes a value of implemented interventions. This is an important issue often overlooked in studies which should be taken into account according to the methodology of evaluating public interventions [Adelle, Weiland 2012; OECD 2011]. Changing the quality of life is one of such benefits. Research on changes in this area requires both quantitative and qualitative data. Therefore, the raw data collected by the Ministry of Development for a study ,The impact of cohesion policy on urban development in 2007-2013,' was used for the paper. The research was carried out in 2017 in all cities with more than 100,000 inhabitants. It was conducted using the following research methods: (a) analysis of available documents, scientific publications, analyses and expert opinions on the subject; (b) meta-evaluation; (c) individual in-depth interviews with representatives of the city offices - 67; (d) individual in-depth interviews with representatives of the managing and intermediary institutions of the operational programmes implemented in 2007-2013 - 63, (e) individual in-depth interviews with beneficiaries (representatives of institutions which implemented the projects) - 46, (f) questionnaire survey among beneficiaries of support, i.e. entities which received funds for the implementation of projects under the cohesion policy in 2007-2013 - 1800. A survey among users of the implemented projects (representatives of entrepreneurs, academics, local NGOs, residents) using the PAPI method was conducted on a sample of 800 in selected cities, including Warsaw.

The data relating to Mazovia were analysed for the article, in particular in-depth interviews with representatives of the city offices covered by the study (departments and offices responsible for the city development, implementation of the strategy, implementation of projects co-funded by the EU in 2007-2013 in Warsaw, Radom and Płock) and a survey of the beneficiaries of urban projects implemented under operational programmes financed by EU funds. The survey was conducted using the CAWI/CATI mixed method.

\section{Urban quality of life in the light of the theory}

The quality of life is a multidimensional phenomenon and refers to concepts such as emotional, physical, material and social well-being. It lacks a single definition in the literature and its multiplicity and diversity are more frequently mentioned [Rapley 2003]. The literature, however, relatively commonly refers to the quality of life (cities included) as to the level of development of surroundings that allows fulfilling the needs of residents, on the individual level and in relation to economic relations [Carvalho et al. 2018; Amado et al. 2019; Diener 
2006; Nefs et al. 2013]. This concept is gaining importance when designing and implementing public policies, including urban policies. With the growing importance of soft factors of urban competitiveness (related to the quality of life, difficult to measure, referring to the quality not the quantity of resources, e.g. social capital, norms and trust, local entrepreneurship culture, quality of the natural and social environment, cultural resources, local identity, international image, [cf. Bronisz 2013; Łaźniewska 2015; Szczech-Pietkiewicz 2019], references to this notion become more significant, and the importance of the quality of life in the assessment of the effectiveness of development activities is growing. The significance of the issue of quality of life in cities can be attributed to two factors [Lambiri, Biagi, Royuela 2007; Biagi, Ladu, Meleddu 2018]. The first being the inclusion of this issue in development policies, as well as a possibility of using it as a political tool. Within the European Union, comparisons of the level of economic and social development are the basis for designing cohesion tools. Increasing the quality of life is their fundamental objective. The second reason is that it often lies at the heart of the location decisions of households and businesses.

The conceptual analysis of the term "quality of life" indicates that it can be interpreted in two dimensions: objective - physical, social, economic, etc.; subjective - as a psychological feeling of satisfaction [Nevado-Peña et al. 2019]. The subjective approach refers to how people use resources available to them [Kahneman, Deaton 2010] and is a result of the possible opportunities they have [Sen 2011].

The conceptualisation of the notion of urban quality of life used for designing urban policies usually takes the form of rankings (e.g. Mercer Quality of Living Survey, Local Human Development Index UNDP, OECD regional Indicator, EIU Global Liveability Ranking, Monocle's Quality of Life Survey). Literal references to such rankings bring about limitations to the research and management of a city, e.g.: oversimplification of reality, promotional character and the risk of subordinating development goals of a city to the guidelines of a specific ranking [Szczech-Pietkiewicz 2019]. Such rankings, however, enable the objectification of the assessment of the quality of life.

The subjective assessment made by residents is an equally popular method of evaluating the quality of life in cities. The issues of respondents' different points of reference, expectations or even their psychological features are often emphasized in the studies [Diener 2006; McCrea, Shyy, Stimson 2006]. Nevertheless, the subjective assessment of the quality of life in cities allows capturing the extent to which a standard of living of a person making such assessment matches the formal or informal points of reference. Studies [Angur, Widgery, Angur 2004] confirm that differences in objective and subjective assessment of the urban quality of life become less often as the spatial scale decreases. This is particularly important for the analysis of urban quality of life. The next part of the paper will show the available results of subjective evaluation of the quality of life in Mazovia, and the selected cities of the voivodeship. In light of the limitations presented by both objective and subjective indicators of the quality of life in cities, it seems justified to combine both approaches, e.g. by creating complex indicators. Such an approach is also confirmed by research on urban infrastructure. It has shown that the assessment of the quality of life depends both on the physical acces- 
sibility of urban infrastructure and the degree of satisfaction from using it [Sen 1987, 1993]. The combination of objective (the availability of a good or service) and subjective factors (use and satisfaction) seems to be a good way of assessing the effectiveness of cohesion policy and its impact on the urban quality of life. The necessity of combining objective features of an urban environment with the satisfaction from using it is indicated as an important premise for the effectiveness of urban policies aimed at improving the quality of life [McCrea, Shyy, Stimson 2006; Biagi, Lady, Meeddu 2018]. Taking into account the goal of this paper, it is possible to specify the topics that are most frequently presented in studies on the quality of life, with particular emphasis on the local and regional aspects. They include [El Din et al. 2013]: environment; physical factors, especially infrastructure; accessibility and mobility; social factors, especially integration and participation; psychological factors and subjective feelings; economic (work, entrepreneurship) and political factors, i.e. the quality of urban management and legislation.

\section{Areas influenced by the cohesion policy}

The spending of funds on the cohesion policy in the previous financial perspective was characterised by a strong concentration. Approximately 43\% of the funds (PLN 67.4 billion) were allocated to transport investments. About 29\% (PLN 45.3 billion) was allocated to entrepreneurship and innovation. The value of projects implemented in other areas was significantly lower and amounted to: environment and energy - PLN 17.5 billion (11.2\%), revitalisation, protection and development of cultural and historical heritage, tourism - about PLN 12 billion (7.5\%), social infrastructure - PLN 10.5 billion (6.7\%), development of local education and employment - about PLN 4.6 billion (2.9\%). The shares of these areas within the framework of the intervention financed by EU funds in 2007-2013 in Warsaw, Płock and Radom are presented in Figure 1.

The significance of an urban centre (metropolitan centre, subregional centre) significantly differentiates the directions of expenditure. The dominance of transport investments in Warsaw (cf. Fig. 1) results from a high cost of such investments, but also from huge needs, especially in terms of expanding the road network and investing in the public transport. Subregional centres allocated most funds to the development of entrepreneurship and innovation.

Investments in communication and transport infrastructure were also important in Płock and Radom. They made it possible to maintain or expand existing transport connections (Fig. 1). The financing of the construction of the second bridge crossing in Płock, together with the construction of access roads and the ring road improved the accessibility of the city, restoring its function as a regional centre in Mazovia. This was a condition for overcoming the city's basic development obstacle. The development of the airport in conjunction with the ring road and the creation of investment areas was of similar importance. Road and rail connections with Warsaw, not adapted to specific needs, still limit the full restoration of Płock's function as a regional centre. 


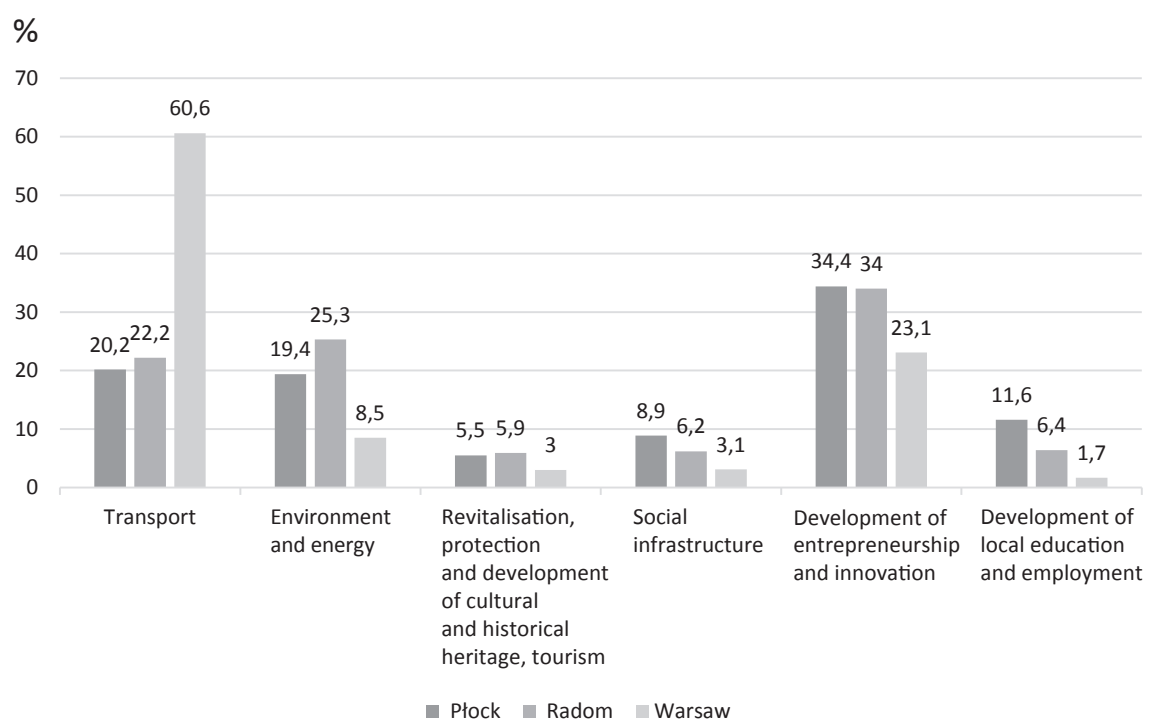

Fig. 1. Share of expenditure under the cohesion policy by thematic areas in large cities in Mazovia Source: own elaboration based on data from the National IT System KSI SIMIK 2007-2013

A relatively large number of environmental and energy investments were also carried out in Radom and Płock (Fig. 1). The obtained funds covered investments in water and sewage management, waste management, promotion of biodiversity, modernisation of energy networks and gas pipelines and obtaining energy from renewable sources.

The number of projects and their value depended primarily on the population and the significance of the urban centre. The total value of the projects reached over PLN 33 billion in Warsaw, PLN 1.6 billion in Radom, and almost PLN 1.2 billion in Płock (Table 1).

Table 1. Projects implemented in large cities in Mazovia

\begin{tabular}{|l|c|c|c|c|r|}
\hline City & $\begin{array}{l}\text { Number of } \\
\text { projects }\end{array}$ & $\begin{array}{l}\text { The total value } \\
\text { of the projects } \\
\text { (in PLN) }\end{array}$ & $\begin{array}{l}\text { Value of EU } \\
\text { funding } \\
\text { (in PLN) }\end{array}$ & $\begin{array}{l}\text { The average } \\
\text { total value of } \\
\text { the projects } \\
\text { (in PLN) }\end{array}$ & $\begin{array}{r}\text { The total value } \\
\text { of the projects } \\
\text { per capita } \\
\text { (in PLN) }\end{array}$ \\
\hline Warsaw & 3743 & 33020684934 & 18052422780 & 8821984 & 18930 \\
\hline Płock & 233 & 1187780874 & 662025048 & 5097772 & 9757 \\
\hline Radom & 446 & 1604615027 & 896393772 & 3597792 & 7423 \\
\hline $\begin{array}{l}\text { Poland } \\
\text { (large } \\
\text { cities) }\end{array}$ & 26563 & 157201277913 & 86421347060 & - & - \\
\hline
\end{tabular}

Source: own elaboration based on data from the National IT System KSI SIMIK 2007-2013 
The positive impact of the 2007-2013 intervention on the improvement of urban quality of life is confirmed by the statements of all key parties involved, i.e. representatives of city halls, business circles and residents. When asked whether living and working conditions had improved over the last 10 years, a vast majority of inhabitants answered positively $(83 \%$ in total), with $13 \%$ declaring that they saw a significant improvement.

The study results suggest that the projects implemented in the area of transport had a positive impact on improving the quality of life in cities (both urban transport and road infrastructure were affected). The transport investments fitted in very well with the needs of city residents. The most urgent issues were both infrastructural deficiencies - e.g. in terms of roads, railway or tram tracks, bicycle paths - and shortages in rolling stock (buses, trams). Furthermore, the construction of the second metro line in Warsaw was a vital project.

The fact that the greatest impact on the quality of life is seen through investments in the area of transport is linked to the volume of spending under the cohesion policy. It is caused by several factors. Firstly, a poor condition of roads before 2007-2013, resulting in inconvenient commuting. Secondly, the improvement of roads and public transport results in saving of time spent on commuting. Thirdly, transport accessibility significantly increases the possibilities of ways of spending free time. Fourthly, this is an area which almost all residents of the cities benefit from. Therefore, most residents see positive changes as being related to investments in transport and public transport.

Thanks to investments in road infrastructure, improving core processes (e.g. traffic management) or road transport solutions under the cohesion policy, the change that took place had the greatest impact on the quality of life of the general population. This is confirmed by the results of qualitative and questionnaire surveys among the inhabitants. When asked about the effects of the implemented projects in the area of transport, the surveyed drafters valued most highly: their impact on improving connections between regional centres, reducing time and costs of travel and transport, increasing travel comfort, improving road safety, improving accessibility to investment areas and existing or planned industrial and service facilities. Between 2008 and 2016, the level of traffic congestion, expressed in terms of extended travel time due to traffic jams, decreased significantly. Moreover, many cities have experienced a change in the characteristics of their urban transport system. Punctuality, speed and comfort of a new generation of buses improved thanks to the EU-funded investments. The interviews and survey carried out among project drafters confirm these findings.

Representatives of the city halls emphasized that projects that encouraged the residents to spend their free time actively, in particular the construction of bicycle paths, improved the quality of life. This contributed to an increase in the popularity of cycling and the promotion of a healthy lifestyle. Sports facilities, which allowed for organizing mass sports and cultural events, were perceived similarly.

The second type of urban space-related projects that influenced the quality of life of the residents are revitalization investments. The goal of such projects was often to integrate residents and provide them with the means to undertake various initiatives and places to spend free time actively. Such functions are currently served by renovated boulevards, city parks, representative streets and other recreational spaces. 
The importance of organised urban greenery in the revitalisation process is vital. Current heavy urbanisation and accompanying environmental degradation make it necessary to take action in the field of sustainable development, i.e. increasing the area of green spaces. The revitalisation of a city park was carried out, among others, in Radom.

According to representatives of the city offices, environmental projects were also very important for the quality of life of the residents. In particular, the construction of sewage treatment plants and sewage systems improved their lives. Although not in a very spectacular way (they are less visible).

The role of projects financed by the ESF is also emphasized, especially those implemented by MOPS. The projects had an impact on equalisation of the standard of living of residents and on limiting social exclusion of children.

The cohesion policy raised awareness of groups in society that require more care. Cities even started applying for certificates e.g. for a senior citizen-friendly city. As all infrastructure investments co-financed by the operational programmes 2007-2013 had to be adapted to the needs of the disabled, awareness increased among both beneficiaries and contractors. It will have an impact on future investments since a certain way of thinking got well-rooted. This also improves the situation of the disabled, who can now reach many places thanks to the investments.

It can be concluded based on the analysis that among the urban development projects implemented under the cohesion policy in 2007-2013 - transport; environment and energy; revitalisation, protection of cultural heritage and tourism; social infrastructure; entrepreneurship and innovation; development of local education; development of local employment - the areas indicated in Figure 2 were of the greatest importance to the quality of life.

\section{The revitalisation, protection of cultural heritage and tourism}
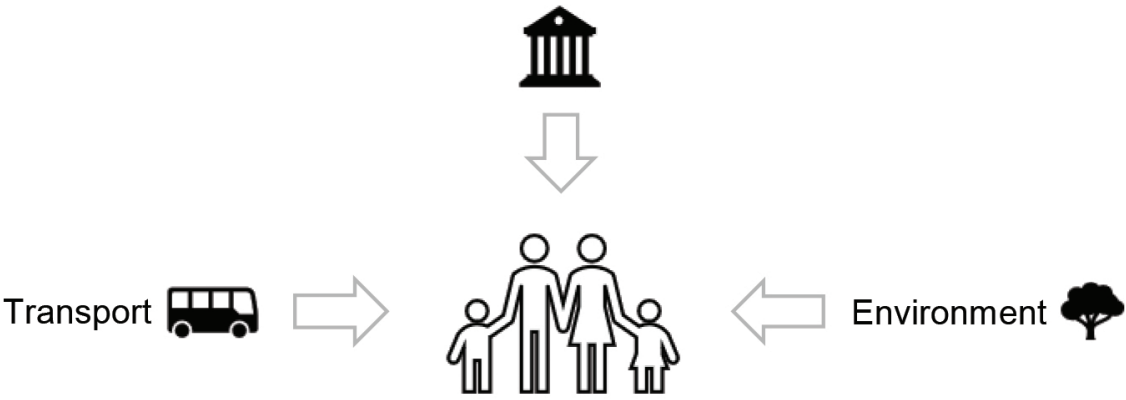

\section{Quality of life of residents}

Fig. 2. Areas of intervention within the framework of the cohesion policy having the greatest impact on the quality of life in large cities 


\section{Quality of life in the cities in Mazovia in empirical research}

The above-mentioned rankings and analyses on the quality of life usually cover the whole country. They most often aim at selected cities, with the selection favouring large cities or those of significant administrative importance. With this in mind, one should pay attention to the periodical GUS study "Regional differences in the quality of life." It refers to the issue of social cohesion in a regional perspective and provides data on selected life quality indicators in Mazovia (Table 2).

Table 2. Selected indicators of the quality of life in Mazovia and average for Poland in 2018

\begin{tabular}{|c|c|c|c|}
\hline Indicator & Description of the indicator & $\begin{array}{l}\text { Value for } \\
\text { Mazovia }\end{array}$ & $\begin{array}{l}\text { The average } \\
\text { value for Poland }\end{array}$ \\
\hline $\begin{array}{l}\text { Life satisfaction in } \\
\text { general }\end{array}$ & $\begin{array}{l}\% \text { of those aged } 16 \text { and older who } \\
\text { are satisfied with their lives in } \\
\text { general }\end{array}$ & 84 & 83 \\
\hline $\begin{array}{l}\text { Relative income- } \\
\text { related poverty }\end{array}$ & $\begin{array}{l}\% \text { of households where income in } \\
\text { the preceding } 12 \text { months was below } \\
\text { the poverty line }\end{array}$ & 9 & 13 \\
\hline $\begin{array}{l}\text { Indicator of high- } \\
\text { income }\end{array}$ & $\begin{array}{l}\% \text { of households where the monthly } \\
\text { income was higher than } 5 / 3 \text { of } \\
\text { the median income of all national } \\
\text { households }\end{array}$ & 27 & 15 \\
\hline $\begin{array}{l}\text { Indicator of poor } \\
\text { living conditions }\end{array}$ & $\begin{array}{l}\text { \% of households where at least } 10 \\
\text { signs of poor living conditions were } \\
\text { observed }\end{array}$ & 4 & 5 \\
\hline $\begin{array}{l}\text { Indicator of good } \\
\text { living conditions }\end{array}$ & $\begin{array}{l}\% \text { of households where no sign of } \\
\text { poor living conditions was found }\end{array}$ & 27 & 27 \\
\hline $\begin{array}{l}\text { Exposure to air } \\
\text { pollution during } \\
\text { the summer months }\end{array}$ & $\begin{array}{l}\text { \% of households exposed to air } \\
\text { pollution during the summer } \\
\text { months }\end{array}$ & 9 & 6 \\
\hline $\begin{array}{l}\text { Exposure to air } \\
\text { pollution during } \\
\text { the winter months }\end{array}$ & $\begin{array}{l}\% \text { of households exposed to air } \\
\text { pollution during the winter months }\end{array}$ & 14 & 14 \\
\hline $\begin{array}{l}\text { Satisfaction with } \\
\text { green spaces }\end{array}$ & $\begin{array}{l}\% \text { of people aged } 16 \text { and older who } \\
\text { are satisfied with green areas }\end{array}$ & 78 & 79 \\
\hline $\begin{array}{l}\text { Sense of security at } \\
\text { home }\end{array}$ & $\begin{array}{l}\% \text { of people aged } 16 \text { and older } \\
\text { declaring that they feel very safe } \\
\text { walking alone in their area after } \\
\text { dark }\end{array}$ & 91 & 89 \\
\hline
\end{tabular}




\begin{tabular}{|l|l|c|r|}
\hline Indicator & \multicolumn{1}{|c|}{ Description of the indicator } & $\begin{array}{r}\text { Value for } \\
\text { Mazovia }\end{array}$ & $\begin{array}{r}\text { The average } \\
\text { value for Poland }\end{array}$ \\
\hline $\begin{array}{l}\text { Percentage of people } \\
\text { satisfied with their } \\
\text { place of residence }\end{array}$ & $\begin{array}{l}\text { \% of people aged 16 and older who } \\
\text { are satisfied with their place of } \\
\text { residence }\end{array}$ & 80 & 80 \\
\hline $\begin{array}{l}\text { General trust in } \\
\text { people }\end{array}$ & $\begin{array}{l}\text { \% of people aged 16 and older } \\
\text { demonstrating general confidence } \\
\text { in people }\end{array}$ & 79 & 80 \\
\hline
\end{tabular}

Source: own elaboration based on GUS. 2019. Regional differences in the quality of life in 2018. Results of the Social Cohesion Survey 2018, taken from https://stat.gov.pl/download/gfx/portalinformacyjny/pl/ defaultaktualnosci/5486/31/1/1/regionalne_zroznicowanie_jakosci_zycia_w_polsce_w_2018_roku.pdf [accessed: 29.01 .2020 ]

The results of the Social Cohesion Survey 2018 present Mazovia as a voivodeship that offers a higher quality of life than the national average. However, it is not in extremely high positions on the ranking (except for indicators concerning the income of households). On the other hand, the findings on the living conditions of households, the quality of the environment, satisfaction with green spaces and trust are similar to the national average. The indicators analysed in the GUS survey refer to the issue of cohesion, thus they may show the effectiveness of actions financed by the cohesion policy, which is analysed further in this paper.

Another study on Mazovia, 'Analysis of the standard of living in cities of the Mazovian Voivodeship in 2014', was conducted by the Mazovian Centre for Regional Surveys. When referring to the results of the analysis, it is worth noting that although they provide more historical data, the cities of the Mazovian Voivodeship are the main subject of the study. It is also necessary to note that 'Analysis...' refers to the concept of the standard of living, which is not the same as the quality of life. Despite these limitations and time range, this publication is still valuable due to its subject matter, i.e. the cities in Mazovia, and gives a cross-sectional view of urban centres in the voivodeship. Warsaw was excluded from the analysis, due to its central character and the dominant role of a growth pole. Concerning the synthetic measure of the standard of living, it was shown that the cities located closest to Warsaw, both in the east and the west, are characterised by the highest level of living. This is mainly due to the conditions on the Warsaw job market. The cities analysed within the framework of this paper (Płock and Radom) were included in the group of cities with a very low value of the indicator of standard of living. An interesting connection was observed when analysing a relation between the standard of living and the city size. It was shown that the synthetic life standard measure increases with the size of a centre. Two cities, Płock and Radom, are an exception. Despite having the largest population, their result was only slightly higher than the smallest cities, i.e. below 5 thousand inhabitants. The survey conducted by the authors of 'Analysis...' present Radom and Plock as cities facing big challenges ahead. These two centres ranked last among the subregional cities in the synthetic quality of life index. Even though the data presented may already be out of date they present general trends in the spatial distribution of the standard of living and the relationships between individual factors. At the same time, they 
justify the choice of Płock and Radom as the subject of analysis in relation to the effects of the implementation of the cohesion policy, especially in terms of the quality of life in these cities.

'The analysis ...' addressed the issue of the standard of living in Mazovian cities with the exception of Warsaw. The quality of life in Warsaw is monitored by the Warsaw City Hall and periodically examined by a survey among residents. The most recent survey carried out in 2015 (City Hall of Warsaw 2015) indicate that the residents of Warsaw are satisfied with life in this city ( $94 \%$ of respondents). This shows an upward trend in comparison with previous periods. The areas which were particularly highly rated were education, public transport and cultural offer. Among the public services which, according to the population of Warsaw, require significant improvement were: the number of parking spaces, the condition of road infrastructure, sports and recreation, the quality of social care and the quality of service provided to residents visiting district councils. Traffic and noise also influenced the quality of life in Warsaw. The subjective evaluation of the economic situation of residents describing their situation as 'we are rather/very well off'reached 70.

'The National Report on Social Development. Poland 2012. Regional and local development' [UNDP 2012] plays a very important role in the review of empirical studies on the quality of life in Mazovia. Even though a historic period is being analysed (i.e. 2007-2010), the study has the advantage of being the only one attempting to estimate the local level of HDI (LHDI) in Poland. The compilation represents local level by the county perspective through three areas of interest: economic performance (WI - wealth index), population health (HI - health index) and quality of education (EI - education index). The results of quantitative analyses carried out for the need of LHDI established the theoretical relationship between income and wealth and quality of life (Easterlin's paradox, indicating that in countries over a certain level of wealth, an increase in income over time does not cause an increase in satisfaction, which can be explained by an increase in aspirations and desires along with an accumulation of wealth). It shows that the level of social development depends on other factors, including the qualitative ones, such as the quality of human capital, the importance of social cohesion or health condition determined by the quality of the environment. The quantitative results of LHDI for the Mazovian Voivodeship and the cities analysed in the article are presented in Table 3.

Table 3. LHDI index values and its components for Mazovia and selected Mazovian cities in 2010

\begin{tabular}{|l|c|c|c|c|c|}
\hline \multicolumn{1}{|c|}{ Territorial unit } & Change in position compared to 2007 & LHDI & HI & EI & WI \\
\hline Mazovia Voivodeship & 0 & 60,21 & 58,18 & 61,68 & 60,84 \\
\hline Warsaw & 0 & 87,63 & 68,97 & 97,75 & 99,83 \\
\hline Płock & -1 & 56,71 & 50,87 & 61,67 & 58,12 \\
\hline Radom & +6 & 49,39 & 55,85 & 58,72 & 36,73 \\
\hline
\end{tabular}

Source: own elaboration based on UNDP, National Report on Social Development. Poland 2012. Regional and local development. Warsaw: UNDP Project Office in Poland 
The UNDP report [2012] emphasises that quantitative results cannot fully reflect the complexity of the issue of human development. This is relatively important when discussing the data for Mazovia as a whole voivodeship, but also for the city of Warsaw alone. The results are diverse within particular counties of the Mazovia region and the occurrence of the "Warsaw Island" is observed i. e. a significantly positive impact of the Warsaw agglomeration on the results of the region but also a high diversification of these results within the city itself.

The UNDP study also addresses a very important problem of the impact of public policies on social development. It attempted to measure the relationship between interventions and social development, thus creating the LHDIPI index. It takes into account public expenditure from the local government budget (LEIPI), medical and nursing availability (HIPI), expenditure on education and the ratio of teachers to students (EIPI). The ranking, based on the above, places Mazowieckie Voivodeship on the sixth position in Poland. The county-level analysis allowed to identify those areas surrounding the agglomerations (including Warsaw) with a very low level of expenditures on public policies. Detailed values of the LHDIPI index for the cities analysed in the article are presented in Table 4.

Table 4. Local social development index of public policy expenditures (LHDIPI) for the Masovian Voivodeship and selected Masovian cities in 2010

\begin{tabular}{|l|c|c|c|c|}
\hline Territorial unit & LHDI $_{\mathrm{PI}}$ & $\mathrm{HI}_{\mathrm{PI}}$ & $\mathrm{EI}_{\mathrm{PI}}$ & LEI $_{\mathrm{PI}}$ \\
\hline Mazovian Voivodeship & 35,89 & 32,71 & 40,89 & 34,55 \\
\hline Warsaw & 55,67 & 51,91 & 56,74 & 58,58 \\
\hline Płock & 45,26 & 53,97 & 42,88 & 40,05 \\
\hline Radom & 33,56 & 46,67 & 33,49 & 24,19 \\
\hline
\end{tabular}

Source: as in table 2

Greater public spending translates into the higher quality of life thanks to the availability of public services in terms of both their existence and usefulness, which are an important element of the quality of life in cities. In this context, the results of Radom and Plock (below the average in each LHDI PI area, in some cases significantly) are consistent with the previously presented results of analyses of the level and quality of life in these cities. The challenges, that can be dealt with using funds of the cohesion policy, are especially visible in the areas of education and wealth in these cities.

\section{Conclusions and recommendations}

Infrastructural investments improving the quality of life have become an important factor pulling cities out of the civilisation backwardness. Investments improving the communication accessibility of cities facilitated the migration processes from central cities to suburban zones (suburbanisation). Construction of convenient infrastructure made it possible to move outside the city limits while maintaining many civilisational standards in terms of technical 
infrastructure. This met the expectations of city dwellers, encouraging them to live in suburban areas with lower population density and a better natural environment. On the other hand, the implementation of the cohesion policy 2007-2013 favoured the development of settlement systems, e.g. through investments related to the revitalisation of downtown areas or historic centres. It promoted the implementation of the concept of a compact city. The results of the study on the impact of cohesion policy on urban development in 2007-2013 show that the city authorities, when making investments using structural funds, paid little attention to the problem of disproportion between factors threatening the integration and hindering the achievement of the intended social objectives and factors leading to balanced development and strengthening of the region's development resources. In an effort to immediately improve the quality of life, the focus was put on solving problems and modernising infrastructure only partially.

The concept of the quality of life in cities is becoming more and more important. Not only within the academic debate but also in public policies. Soft factors are an important motive for the location choices of enterprises and city residents. This is also the reason why funds from the cohesion policy are heavily involved in this area of urban development.

The studies confirm such findings, indicating that expenditures under the cohesion policy are highly related to the level of the city's development, mainly in its social element. The amount of expenditures from EU funds within the municipal budgets is strongly correlated with the LHDI value. The analysis of the data confirms that through changes in the most important areas - communication, infrastructure for spending free time and the quality of the environment (revitalisation) - one can observe the impact of the cohesion policy on large cities in Mazovia.

The need for funding of the cohesion policy in the Mazovian cities is justified by the comparison of the indicators of standard of living in the region. The indicator in Płock and Radom reached a level comparable to that of the smallest cities, with the general tendency being for it to increase its value along with the city size.

In terms of the city size, the analysis of expenditures incurred in the analysed period indicates that the rank of the city centre significantly differentiates the directions of expenditures. Warsaw is dominated by high-cost transport investments. On the other hand, subregional centres allocated the most funds to the development of entrepreneurship and innovativeness. The investments in Płock supported the development of the city as a subregional centre, among others, through the construction of the second bridge crossing and the airport development in connection with the ring road and the creation of investment areas.

The literature defining the quality of life in cities shows that simply investing in infrastructure is not enough [Sen 1987, 1993; McCrea, Shyy, Stimson 2006; Biagi, Lady, Meeddu 2018]. It is important to link such projects with the recipient's satisfaction and usefulness of a good or service. In this context, the analysis of cohesion policy funding aimed at improving the quality of life shows that change can be positively assessed. The quality of life improved both through investment in hard road infrastructure and improvement of related mainte- 
nance processes. Changes in the Mazovian cities also took place in terms of the urban transport features, such as punctuality, speed of travel or the comfort of travelling.

When considering the subjective and objective evaluation of the quality of life, conclusions concerning the perception of the impact of the cohesion policy on life formulated by the inhabitants of Mazovian cities should be highlighted. The results of the study show that projects implemented in the area of transport had a significant impact on the improvement of the quality of life in cities (this concerns both urban transport and road infrastructure). The improvement was mainly achieved in the fields of commuting time, safety and driving comfort. Stakeholders in Warsaw see an improvement in the quality of public transportation, surroundings' appearance, and the level of prosperity.

Challenges for future financial periods in the area of quality of life in large cities in Mazovia are related to, among others, the effects of treating problems in a fragmented way and unfinished modernization of the infrastructure. Even though such an approach had a positive impact on the development of cities and the entire region, it increased the risk of triggering structural development dysfunctions. The development of the function of regional centres in the analysed cities (Płock and Radom), e.g. by modernising transport connections and creating a regional system, is a future requirement.

\section{References}

Adelle C. and Weiland S. 2012, Policy assessment: the state of the art, Impact Assessment and Project Appraisal, 30, 1, pp. 25-33.

Amado C.A.F., Barreira A.P., Santos S.P., Guimarães M.H., 2019, Comparing the quality of life of cities that gained and lost population: An assessment with DEA and the Malmquist index, Papers in Regional Science, 98, pp. 2075-2097.

Analiza poziomu życia w miastach województwa mazowieckiego w 2014 r., 2016, Mazowiecki Ośrodek Badań Regionalnych, Urząd Statystyczny, Warszawa.

Angur M.G., Widgery R., Angur S.G., 2004, Congruence among objective and subjective qualityof-life (QOL) Indicators, Alliance Journal of Business Research, pp. 47-54.

Biagi B., Ladu M.G., Meleddu M., 2018, Urban quality of life and capabilities: An experimental study, Ecological Economics, 150, pp. 137-152.

Bronisz U., 2013, Metody badania konkurencyjności regionów, Studia KPZK PAN, 150, Komitet Przestrzennego Zagospodarowania Kraju PAN, Warszawa.

Carvalho J. M. S., Costa R. V., Marnoto S., Sousa C. A. A., Vieira J. C., 2018, Toward a resource-based view of city quality - a new framework, Growth and Change: A Journal of Urban and Regional Policy, 49, 2, pp. 266-285. 
Cloutier S., Larson L., Jambeck J., 2014, Are sustainable cities "happy" cities? Associations between sustainable development and human well-being in urban areas of the United States, Environment, Development, Sustainability, 16, 3, pp. 633-647.

Diener E., 2006, Guidelines for national indicators of subjective well-being and ill-being, Journal of Happiness Studies, 7, 4, pp. 397-404.

El Din H.S., Shalaby A., Farouh H.E., Elariane S.A., 2013, Principles of urban quality of life for a neighbourhood, HBRC Journal, 9, 1, pp. 86-92.

Główny Urząd Statystyczny, 2019, Regionalne zróżnicowanie jakości życia w 2018 r. Wyniki Badania spójności społecznej 2018. Pobrane z: https://stat.gov.pl/obszary-tematyczne/warunki-zycia/dochody-wydatki-i-warunki-zycia-ludnosci/regionalne-zroznicowanie-jakosci-zycia-w-polscew-2018-roku-wyniki-badania-spojnosci-spolecznej-2018,31,1.html, [available: 29.01.2020].

Johnson M. (ed.), 2012, Documents on Government and the Economy, Research in the History of Economic Thought and Methodology, 30, 2, Emerald Group Publishing Limited.

Kahneman D., Deaton A., 2010, High income improves evaluation of life but not emotional well-being, Proceedings of National Academy of Science, 107, 38, pp. 16489-16493.

Krajowy System Informatyczny KSI SIMIK 2007-2020.

Lambiri D., Biagi B., Royuela V., 2007, QoL in the economic and urban economic literature, Social Indicators Research, 84, 1, pp. 1-25.

Łaźniewska E., 2015, Rozwój regionalny a planowanie przestrzenne, Biuletyn KPZK PAN, 257/258, Komitet Przestrzennego Zagospodarowania Kraju PAN, Warszawa, pp. 144-161.

McCrea R., Shyy T-K., Stimson R., 2006, What is the Strength of the Link Between Objective and Subjective Indicators of Urban Quality of Life? Applied Research in Quality of Life, 1, 1, pp. 79-96.

Mitchell R., 2013, Is physical activity in natural environments better for mental health than physical activity in other environments? Social Science and Medicine, 91, pp. 130-134.

Nefs M., Alves S., Zasada I., Haase D., 2013, Shrinking cities as retirement cities? Opportunities for shrinking cities as green living environments for older individuals, Environment and Planning A, 45, 6, pp. 1455-1473.

Nevado-Peña D., Lopez-Ruíz V.-R., Alfarro-Navarro J.-R., 2019, Improving quality of life perception with ICT use and technological capacity in Europe, Technological Forecasting \& Social Change, 148, pp. 1-11.

OECD, 2011, Evaluating public support for innovation in business: Methodologies and metrics [in:] Business Innovation Policies, Selected Country Comparisons, OECD Publishing.

Rapley M., 2003, Quality of life research: A critical introduction, Sage, London. 
Robinson D.T., Murray-Rust D., Rieser V., Milicic V., Rounsevell M., 2012, Modelling the impacts of land system dynamics on human well-being: Using an agent-based approach to cope with data limitations in Koper, Slovenia, Computers, Environment and Urban Systems, 36, 2, pp. 164-176.

Sen A., 1987, On ethics and economics, Blackwell, Oxford.

Sen A., 1993, Capability and well being [in:] M.C. Nussbaum, A. Sen (eds.), The Quality of Life, Wider Studies in Development Economies, Clarendon Press, Oxford.

Sen A., 2011, Quality of Life: India vs. China. The New York Review of Books. Pobrano z: https:// www.nybooks.com/articles/2011/05/12/quality-life-india-vs-china/ [available: 27.07.2020].

Stiglitz J.E., 2004, Ekonomia sektora publicznego, Wydawnictwo Naukowe PWN, Warszawa.

Szczech-Pietkiewicz E., 2019, Konkurencyjność miasta w kontekście wspótczesnych koncepcji teoretycznych i zjawisk gospodarczych, Oficyna Wydawnicza SGH, Warszawa.

Thompson W., Roe, J., Aspinall P., Mitchell R., Clow A., Miller D., 2012, More green space is linked to less stress in deprived communities: Evidence from salivary cortisol patterns, Landscape and Urban Planning, 105, 3, pp. 221-229.

United Nations Development Programme, 2012, Krajowy Raport o Rozwoju Społecznym. Polska 2012. Rozwój regionalny i lokalny, Biuro Projektowe UNDP, Warszawa.

Urząd Miasta st.Warszawy, 2015, Badanie jakości życia mieszkańców warszawskich dzielnic 2015. Pobrano z: http://jakosczycia.um.warszawa.pl/ [available: 29.01.2020]. 


\section{Wpływ polityki spójności na jakość życia w dużych miastach na Mazowszu}

\section{STRESZCZENIE}

We współczesnej polityce miejskiej przykłada się dużą wagę do poprawy jakości życia mieszkańców. Rosnące zainteresowanie polityki miejskiej jakością życia wynika z faktu, że jest ona kluczowa dla decyzji lokalizacyjnych gospodarstw domowych i przedsiębiorstw. W ostatnich latach rozwój miast finansowany był w dużej mierze za pomocą funduszy w ramach polityki spójności Unii Europejskiej. Celem artykułu jest identyfikacja obszarów, w których dokonała się poprawa jakości życia mieszkańców dużych miast na Mazowszu, dzięki realizacji polityki spójności. W badaniu zostały wzięte pod uwagę duże miasta zlokalizowane na Mazowszu, o liczbie mieszkańców powyżej 100 tys., czyli Warszawa, Radom i Płock.

Badanie opiera się na danych zebranych na potrzeby projektu badawczego Wptyw polityki spójności na rozwój miast w perspektywie 2007-2013, które zostały udostępnione przez Ministerstwo Rozwoju, w tym wywiady pogłębione z przedstawicielami komórek odpowiedzialnych za strategię rozwoju w miastach objętych badaniem oraz badanie ankietowe beneficjentów projektów współfinansowanych z funduszy unijnych realizowanych na obszarze miast. Na potrzeby artykułu przeprowadzona została także analiza baz danych dotyczących projektów realizowanych w dużych miastach na Mazowszu, finansowanych z udziałem środków unijnych, a także kwerenda literatury dotyczącej jakości życia w miastach na Mazowszu.

Wyniki analizy wskazuja, że mieszkańcy najbardziej dostrzegają poprawę jakości życia w związku z poprawą transportu w miastach. Jakość życia wzrosła dzięki szybszym i bardziej komfortowym dojazdom do pracy, co pozostawia więcej czasu na inne aktywności i spędzanie czasu wolnego.

Słowa kluczowe: miasta, polityka spójności, jakość życia, Mazowsze

\footnotetext{
Marta Mackiewicz, PhD - specializes in issues related to innovation of economy and regional economy; contact to the author: Warsaw School of Economics, Collegium of World Economy, al. Niepodległości 162, 02-554 Warszawa, e-mail:mmackie@sgh.waw.pl Marta Mackiewicz, dr - specjalizuje się w zagadnieniach zwiqzzanych z innowacyjnościa gospodarki i ekonomii regionalnej; kontakt do autorki:Szkoła Główna Handlowa w Warszawie, Instytut Gospodarki Światowej, al. Niepodległości 162, 02-554 Warszawa, e-mail: mmackie@sgh.waw.pl
}

Ewelina Szczech-Pietkiewicz, PhD - specializes in urban development and issues related to the competitiveness of the economy; contact to the author: Warsaw School of Economics, Collegium of World Economy, al. Niepodległości 162, 02-554 Warszawa, e-mail: eszcze@sgh.waw.pl

Ewelina Szczech-Pietkiewicz, dr - specjalizuje się w rozwoju miejskim i zagadnieniach zwiqzanych z konkurencyjnościa gospodarki; kontakt do autorki: Szkoła Główna Handlowa w Warszawie, Instytut Gospodarki Światowej, al. Niepodległości 162, 02-554 Warszawa, e-mail:eszcze@sgh.waw.pl 